\title{
Formation of oxygen vacancies in ceria-zirconia nanocrystals studied by spectroscopic techniques
}

\author{
E.N.Okrushko, V.V.Seminko, P.O.Maksimchuk, \\ I.I.Bespalova, Yu.V.Malyukin
Institute for Scintillation Materials, STC "Institute for Single Crystals" National Academy of Sciences, 60 Nauky Ave, 61072 Kharkiv, Ukraine

Received July 23, 2018

\begin{abstract}
Incorporation of doped ions with different ionic radius (like $\mathrm{Zr}^{4+}$ ) or valence state (like $\mathrm{Eu}^{3+}$ ) into $\mathrm{CeO}_{2}$ structure leads to sufficient modification of the processes of oxygen transport due to formation of additional oxygen vacancies $\left(\mathrm{O}_{v}\right)$. These vacancies can form complexes with doped ions $\left(\mathrm{RE}-\mathrm{O}_{v}-\mathrm{RE}\right)$ or cerium ions $\left(\mathrm{Ce}^{3+}-\mathrm{O}_{v}-\mathrm{Ce}^{3+}\right)$ determining the oxygen mobility in these structures. In the paper the formation of oxygen vacancies in ceria $\left(\mathrm{CeO}_{2-x}\right)$ and ceria-zirconia $\left(\mathrm{CeO}_{2}-\mathrm{ZrO}_{2}\right)$ nanocrystals was studied by conventional spectroscopic techniques. Ratio between intensities of ${ }^{5} D_{0} \rightarrow{ }^{7} F_{1}$ and ${ }^{5} D_{0} \rightarrow{ }^{7} F_{2}$ spectral lines of $\mathrm{Eu}^{3+}$ ions was used for determination of the content of oxygen vacancies and their location within ceria-zirconia nanocrystal. It was shown that while high-temperature treatment of $50 \mathrm{~nm}$ ceria nanocrystal in reducing atmosphere leads only to slight change of the content of oxygen vacancies which are formed preferably near its surface, incorporation of $20 \%$ of zirconium ions is manifested in almost tenfold increase of the content of oxygen vacancies as compared to $\mathrm{CeO}_{2-x}$ nanocrystal, and these vacancies are formed within whole nanoparticle.

Keywords: ceria-zirconia, nanocrystal, oxygen vacancies, luminescence.
\end{abstract}

Введение примесных ионов, отличающихся по ионному радиусу (например, $\mathrm{Zr}^{4+}$ ), или неизовалентных ионов (например, $\mathrm{Eu}^{3+}$ ) в структуру $\mathrm{CeO}_{2}$ приводит к модификации процессов транспорта кислорода за счет образования дополнительных кислородных вакансий $\left(\mathrm{O}_{v}\right)$. Эти вакансии могут образовывать комплексы с примесными ионами $\left(\mathrm{RE}-\mathrm{O}_{v}-\mathrm{RE}\right)$ или ионами церия $\left(\mathrm{Ce}^{3+}-\mathrm{O}_{v}-\mathrm{Ce}^{3+}\right)$, определяя подвижность кислорода в этих структурах. Исследовано образование кислородных вакансий в нанокристаллах оксида церия $\left(\mathrm{CeO}_{2-x}\right)$ и смешанных церий-циркониевых оксидов $\left(\mathrm{CeO}_{2}-\mathrm{ZrO}_{2}\right)$ с использованием стандартных спектроскопических методов. Соотношение интенсивностей спектральных линий ${ }^{5} D_{0} \rightarrow{ }^{7} F_{1}$ и ${ }^{5} D_{0} \rightarrow{ }^{7} F_{2}$ ионов $\mathrm{Eu}^{3+}$ использовалось для определения содержания кислородных вакансий и их расположения в нанокристаллах смешанных оксидов. Показано, что высокотемпературная обработка нанокристаллов оксида церия (50 нм) в восстановительной атмосфере приводит лишь к незначительному изменению содержания кислородных вакансий, которые формируются в основном вблизи его поверхности, тогда как введение $20 \%$ ионов циркония приводит к увеличению содержания кислородных вакансий почти в 10 раз по сравнению с нанокристаллами $\mathrm{CeO}_{2-x}$, и данные вакансии образуются не только вблизи поверхности, но и по всему объему наночастицы. 
Дослідження формування кисневих вакансій у нанокристалах змішаних церійцирконісвих оксидів за допомогою спектроскопічних методів. О.М.Окрушко, В.В.Селінько, П.О.Максимчук, І.І.Беспалова, Ю.В.Малюкін.

Введення домішкових іонів, що відрізняються за іонним радіусом (наприклад, $\mathrm{Zr}^{4+}$ ) або неізовалентних іонів (наприклад, $\mathrm{Eu}^{3+}$ ) у структуру $\mathrm{CeO}_{2}$ призводить до модифікації процесів транспорту кисню за рахунок утворення додаткових кисневих вакансій $\left(\mathrm{O}_{v}\right)$. Ці вакансії можуть утворювати комплекси з домішковими іонами $\left(\mathrm{RE}-\mathrm{O}_{v}-\mathrm{RE}\right)$ або іонами церію $\left(\mathrm{Ce}^{3+}-\mathrm{O}_{v}-\mathrm{Ce}^{3+}\right)$, визначаючи рухливість кисню у цих структурах. Досліджено утворення кисневих вакансій у нанокристалах оксиду церію $\left(\mathrm{CeO}_{2-x}\right)$ і змішаних церій-цирконієвих оксидів $\left(\mathrm{CeO}_{2}-\mathrm{ZrO}_{2}\right)$ з використанням стандартних спектроскопічних методів. Співвідношення інтенсивностей спектральних ліній ${ }^{5} D_{0} \rightarrow{ }^{7} F_{1}$ i ${ }^{5} D_{0} \rightarrow{ }^{7} F_{2}$ іонів $\mathrm{Eu}^{3+}$ використовувалося для визначення вмісту кисневих вакансій $\mathrm{i}$ ï розташування у нанокристалах змішаних оксидів. Показано, що високотемпературна обробка нанокристалів оксиду церію (50 нм) у відновлювальній атмосфері призводить лише до незначної зміни вмісту кисневих вакансій, які формуються в основному поблизу його поверхні, тоді як введення 20 \% іонів цирконію приводить до збільшення вмісту кисневих вакансій майже у 10 разів у порівнянні з нанокристалами $\mathrm{CeO}_{2-x}$, і ці вакансії утворюються не тільки поблизу поверхні, але і вздовж всього об'єму наночастинки.

\section{Introduction}

Oxygen mobility is a key parameter in development of effective ionic conductors and catalytic materials based on cerium oxide $\left(\mathrm{CeO}_{2}\right)$ micro- and nanocrystals [1-3]. Recently the role of oxygen mobility in the formation of antioxidant properties of ceria nanocrystals was determined [4]. Oxygen mobility, in turn, is determined by content of oxygen vacancies, and by their ability to form associates with doped or regular $\left(\mathrm{Ce}^{4+}\right)$ ions [5]. Oxygen vacancies in ceria structure can be formed by additional doping of ceria by non-isovalent ions or by ions with smaller ionic radius, as well as by high temperature treatment in reducing atmosphere [6-8]. Incorporation of trivalent (for instance, rare-earth) ion instead of $\mathrm{Ce}^{4+}$ leads to formation of oxygen vacancies required for compensation of excess negative charge. Relative position of oxygen vacancies and rare-earth (RE) ions in RE-doped ceria nanocrystal was investigated recently in $[9,10]$. In [5] it was deduced that for ions with radius smaller than radius of $\mathrm{Gd}^{3+}$ ion oxygen vacancy is localized preferentially in the NN (nearest-neighbor) position to RE ion, while for ions with radius bigger than radius of $\mathrm{Gd}^{3+}$ (such as $\mathrm{Eu}^{3+}$ ions) vacancy is repelled to NNN (next to nearest-neighbor) position. Our own studies [11] confirmed this prediction showing that in $\mathrm{Eu}^{3+}$-doped ceria nanocrystals most part of $\mathrm{Eu}^{3+}$ ions preserve $O_{h}$ symmetry.

Mixed ceria-zirconia $\left(\mathrm{CeO}_{2}-\mathrm{ZrO}_{2}\right)$ have recently attracted a lot of attention as promising material for development of catalytic supports for noble-metal catalysts [12]. High oxygen storage capacity of ceria-zir- conia powders allows them to absorb and release high concentrations of oxygen during operation cycle. These materials are widely used now for three-way catalysis in automotive converters enabling to eliminate simultaneously carbon oxide, nitric oxide and unburned hydrocarbons [13]. Replacing of the part of $\mathrm{Ce}^{4+}$ ions by $\mathrm{Zr}^{4+}$ ones (up to $40 \%$ ) leads to sufficient increase of oxygen storage capacity of ceria-based materials. Smaller size of $\mathrm{Zr}^{4+}$ ion as compared to $\mathrm{Ce}^{4+}$ one leads to distort ion of the local surrounding of doped ion decreasing thereby oxygen vacancy formation energy, and, in this way, making possible formation of oxygen vacancies as on the surface, so in the volume of material [14].

In this paper the peculiarities of oxygen vacancies formation in mixed ceria-zirconia nanocrystals were studied using the luminescence of doped $\mathrm{Eu}^{3+}$ ions. The ratio between intensities of ${ }^{5} D_{0} \rightarrow{ }^{7} F_{1}$ and ${ }^{5} D_{0} \rightarrow{ }^{7} F_{2}$ luminescence bands of $\mathrm{Eu}^{3+}$ ion was used as probe of the content and relative location of oxygen vacancies in ceriazirconia nanocrystals at different zirconium content in ceria structure.

\section{Experimental}

$\mathrm{CeO}_{2}: \mathrm{Eu}^{3+}(0.2,2, \quad 5$ and 10 at. $\%)$ nanocrystals were obtained by Pechini method. Cerium oxide $\mathrm{CeO}_{2}$ (Sigma-Aldrich) was dissolved in the mixture of nitric acid $\left(\mathrm{HNO}_{3}\right)$ and hydrogen peroxide (in 1:1 volume ratio); europium oxide $\mathrm{Eu}_{2} \mathrm{O}_{3}$ (SigmaAldrich) was dissolved in the nitric acid .The solution of $0.75 \mathrm{~g}$ of citric acid and $1 \mathrm{ml}$ of ethylene glycol was added to $20 \mathrm{ml}$ of cerium nitrate $\mathrm{Ce}\left(\mathrm{NO}_{3}\right)_{3}(c=1 \mathrm{~mol} / \mathrm{l})$ solution and $40 \mu \mathrm{l}$ of europium nitrate $\mathrm{Eu}\left(\mathrm{NO}_{3}\right)_{3}(c=$ 


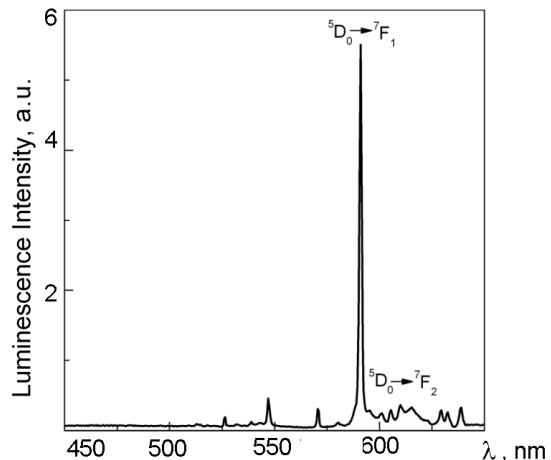

Fig. 1. Luminescence spectra of $\mathrm{CeO}_{2}: \mathrm{Eu}^{3+}$ (a) and reducing (b) atmospheres.

$1 \mathrm{~mol} / \mathrm{l})$ solution. The resulting mixt ure was treated at $80^{\circ} \mathrm{C}$ during $10 \mathrm{~h}$ and then hydrolyzed by means of 10 mass. $\% \mathrm{NH}_{3}$ water solution. The precipitate was dried at $120^{\circ} \mathrm{C}$ during $5 \mathrm{~h}$ and then dehydrated at $250^{\circ} \mathrm{C}$ during $4 \mathrm{~h} \mathrm{CeO}:_{2}: \mathrm{Cu}^{3+}$ nanocrystals were annealed during $2 \mathrm{~h}$ in oxidative (air) and reducing (hydrogen) atmospheres at $1000^{\circ} \mathrm{C}$

$\mathrm{Ce}_{0.9} \mathrm{Zr}_{0.1} \mathrm{O}_{2}: \mathrm{Eu}^{3+}$ and $\mathrm{Ce}_{0.8} \mathrm{Zr}_{0.2} \mathrm{O}_{2}: \mathrm{Eu}^{3+}$ $(C=0.2$ at.\%) nanocrystals were obtained by mixing zirconium sulfate $\mathrm{Zr}\left(\mathrm{SO}_{4}\right)_{2}$, ammonium cerium(IV) nitrate $\left(\mathrm{NH}_{4}\right)_{2} \mathrm{Ce}\left(\mathrm{NO}_{3}\right)_{6}$ and europium chloride $\mathrm{EuCl}_{3}$ water solutions in stoichiometric proportions at room temperature at addition of polyethyleneglycol-octyl-phenylate (OP-10) surfactant ethanol solution. Then 10 wt. $\%$ ammonia water solution was added to the resulting mixture until $\mathrm{pH}=7-8$. After that the mixture was heated up to $80-90^{\circ} \mathrm{C}$ and left at this temperature during few hours and then treated in oxidative atmosphere (air) at $500^{\circ} \mathrm{C}$ during $24 \mathrm{~h}$ and at $1050^{\circ} \mathrm{C}$ during $5 \mathrm{~h}$. $\mathrm{Ce}_{1-}$ ${ }_{x} \mathrm{Zr}_{x} \mathrm{O}_{2}: \mathrm{Eu}^{3+}$ nanocrystals were annealed during $2 \mathrm{~h}$ in reducing (hydrogen) atmosphere at $1000^{\circ} \mathrm{C}$.

Luminescence spectra were obtained using spectrofluorimeter based on the grating monochromator, luminescence was excited by He-Cd laser with $\lambda_{\text {exc }}=325 \mathrm{~nm}$. The luminescence of samples was detected by R9110 Hamamatsu photomultiplier tube. Investigations were carried out at $300 \mathrm{~K}$.

\section{Results and discussions}

Luminescence spectra of $\mathrm{Eu}^{3+}$-doped ceria nanocrystals $(C=0.2$ at. $\%)$ after heat treatment in oxidizing and reducing atmospheres are shown in the Fig. 1 (a and b, respectively). The spectra of the samples treated in oxidizing atmosphere consist of a number of narrow lines in the red region of

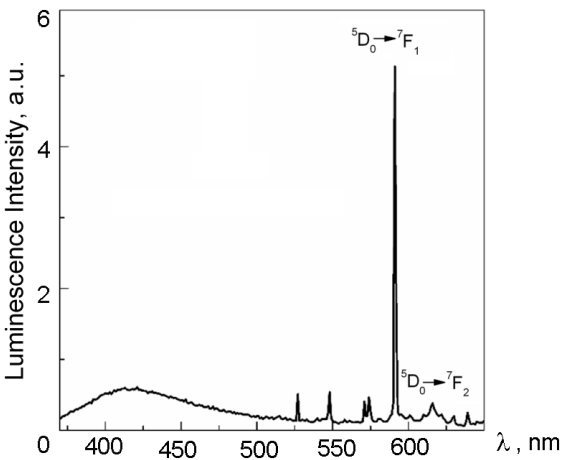

(0.2 at.\%) nanocrystals treated in oxidizing

the spectrum. These lines can be ascribed to different $4 f-4 f$ transitions of $\mathrm{Eu}^{3+}$ ions. $\mathrm{Eu}^{3+}$ ion substitutes $\mathrm{Ce}^{4+}$ ion in the ceria structure, and its lower positive charge is stabilized by formation of additional oxygen vacancies. The ratio between intensities of ${ }^{5} D_{0} \rightarrow{ }^{7} F_{1}$ and ${ }^{5} D_{0} \rightarrow{ }^{7} F_{2}$ luminescence bands of $\mathrm{Eu}^{3+}$ ions allows obtaining the information about oxygen vacancies formed in order to compensate its exc essive charge. This fact is determined by high sensitivity of electro-dipole ${ }^{5} D_{0} \rightarrow{ }^{7} F_{2}$ transition of $\mathrm{Eu}^{3+}$ ion to presence or absence of inversion center of symmetry. Contrary to ${ }^{5} D_{0} \rightarrow{ }^{7} F_{2}$ transition, intensity of magneto-dipole ${ }^{5} D_{0} \rightarrow{ }^{7} F_{1}$ transition of $\mathrm{Eu}^{3+}$ ion is practically independent on the symmetry of cationic center. So the ratio between intensities of ${ }^{5} D_{0} \rightarrow{ }^{7} F_{1}$ and ${ }^{5} D_{0} \rightarrow{ }^{7} F_{2}$ transitions provides information about local symmetry of $\mathrm{Eu}^{3+}$ surrounding and its change during heat treatment. In the luminescence spectrum of $\mathrm{Eu}^{3+}$-doped ceria nanocrystals treated in oxidizing atmosphere (Fig. 1a) the intensity of ${ }^{5} D_{0} \rightarrow{ }^{7} F_{1}$ luminescence band is eight times higher than the intensity of ${ }^{5} D_{0} \rightarrow{ }^{7} F_{2}$ luminescence band. So, for the most part of $\mathrm{Eu}^{3+}$ ions charge compensation occurs by formation of oxygen vacancies beyond the first coordination sphere of $\mathrm{Eu}^{3+}$ ion preserving the inversion center of symmetry for these ions.

Luminescence spectrum of $\mathrm{Eu}^{3+}$-doped ceria nanocrystals after treatment in reducing atmosphere is shown in the Fig. $1 \mathrm{~b}$. Contrary to the spectrum of the samples treated in oxidizing atmosphere, this spectrum consists of the wide band with maximum about $415 \mathrm{~nm}$, and narrow $\mathrm{Eu}^{3+}$ transitions on its background. The assignment of the wide luminescence band for undoped $\mathrm{CeO}_{2-x}$ nanocrystals was discussed in our 

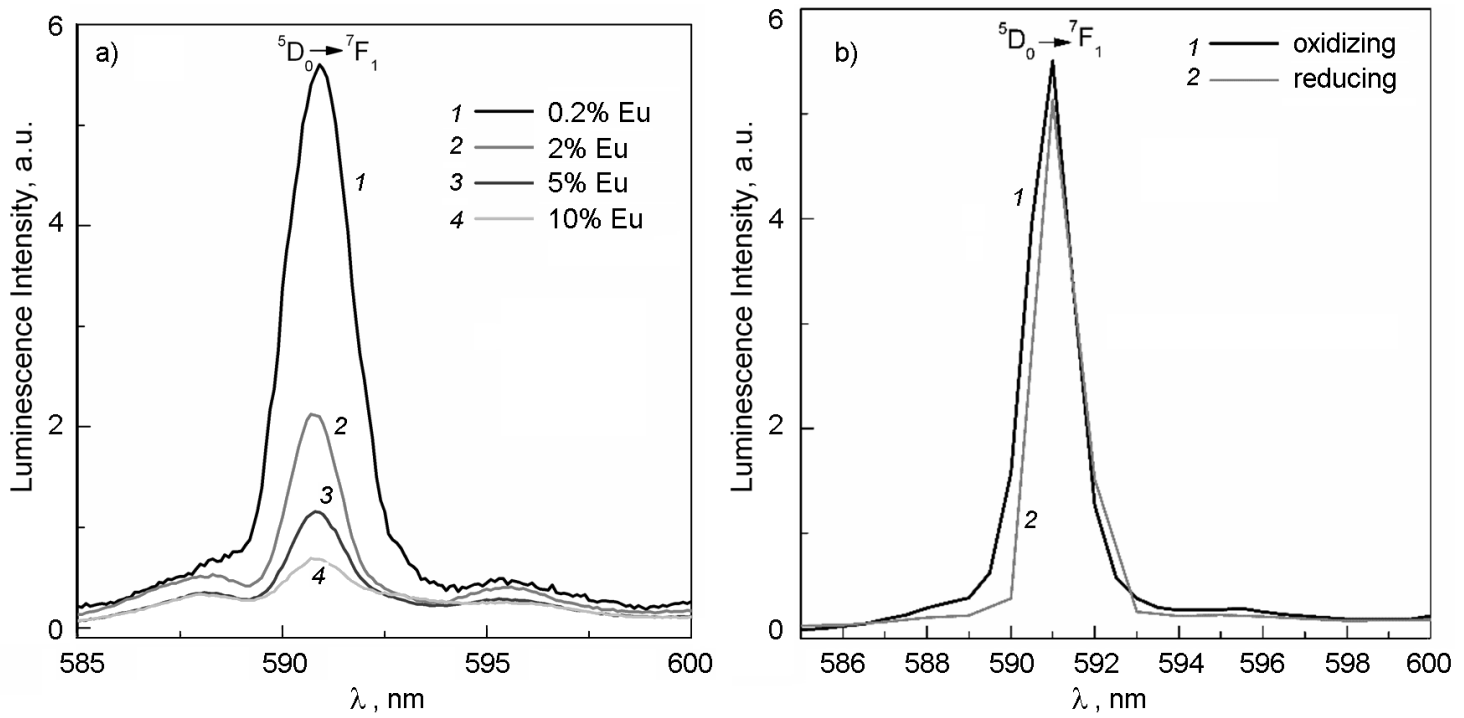

Fig. 2. Luminescence spectra of $\mathrm{CeO}_{2}: \mathrm{Eu}^{3+}$ nanocrystals: (a) with different $\mathrm{Eu}^{3+}$ concentrations $(0.2$, 2, 5 and 10 at. $\%$ ), and (b) $\mathrm{CeO}_{2}: \mathrm{Eu}^{3+}(0.2$ at.\%) nanocrystals treated in different atmospheres. ${ }^{5} D_{0} \rightarrow{ }^{7} F_{1}$ transition is shown only, all spectra are normalized on the intensity of ${ }^{5} D_{0} \rightarrow{ }^{7} F_{2}$ transition.

previous papers [6, 7]. Combination of timeresolved luminescence measurements with study of excitation spectra using synchrotron radiation confirmed that this band is formed by $5 d \rightarrow 4 f$ transitions of $\mathrm{Ce}^{3+}$ ions [6]. Transfer of the part of $\mathrm{Ce}^{4+}$ ions to $\mathrm{Ce}^{3+}$ ions requires corresponding number of oxygen vacancies for charge compensation (one oxygen vacancy for two $\mathrm{Ce}^{3+}$ ions), so this band was not observed for ceria nanocrystals treated in oxidizing atmosphere where formation of oxygen vacancies is suppressed.

In the Fig. 2a luminescence spectra of $\mathrm{Eu}^{3+}$-doped ceria nanocrystals with different $\mathrm{Eu}^{3+}$ concentration are shown. All spectra are normalized to the intensity of ${ }^{5} D_{0} \rightarrow{ }^{7} F_{2}$ transitions, so only ${ }^{5} D_{0} \rightarrow{ }^{7} F_{1}$ spectral lines are shown. Decrease of the intensity of ${ }^{5} D_{0} \rightarrow{ }^{7} F_{1}$ transition should be assigned to the increase of the number of $\mathrm{Eu}^{3+}$ with distorted surrounding (lacking inversion center of symmetry). Introduction of two $\mathrm{Eu}^{3+}$ ions instead of $\mathrm{Ce}^{4+}$ ones into stoichiometric $\mathrm{CeO}_{2}$ lattice leads to formation of one oxygen vacancy required for compensation of excess negative charge. So, the concentration of oxygen vacancies should be proportional to concentration of $\mathrm{Eu}^{3+}$ ions and particular change of ${ }^{5} D_{0} \rightarrow{ }^{7} F_{1}$ intensity can be assigned to particular vacancy concentration. Increase of $\mathrm{Eu}^{3+}$ concentration from 0.2 at. $\%$ to 10 at. $\%$ leads to decrease of intensity of
${ }^{5} D_{0} \rightarrow{ }^{7} F_{1}$ spectral line. So the number of $\mathrm{Eu}^{3+}$ centers with $O_{h}$ symmetry also decreases with increase of $\mathrm{Eu}^{3+}$ concentration. For instance, increase of $\mathrm{Eu}^{3+}$ concentration from 0.2 at. $\%$ to 2 at. $\%$ of $\mathrm{Eu}^{3+}$ ions corresponding to increase of the content of oxygen vacancies from $0.05 \%$ to $0.5 \%$ leads to more than two-fold decrease of the ${ }^{5} D_{0} \rightarrow{ }^{7} F_{1}$ spectral line intensity.

Influence of heat treatment atmosphere on the processes of formation of oxygen vacancies can be deduced from the change of ${ }^{5} D_{0} \rightarrow{ }^{7} F_{1}$ relative intensity as well. In the Fig. 2b luminescence spectra of $\mathrm{Eu}^{3+}$-doped ceria nanocrystals treated in oxidative (air) and reducing (hydrogen) atmospheres are shown. As in Fig. 2a, all spectra are normalized to the intensity of ${ }^{5} D_{0} \rightarrow{ }^{7} F_{2}$ transition, so only ${ }^{5} D_{0} \rightarrow{ }^{7} F_{1}$ spectral line is shown. As can be seen, change of treatment atmosphere form oxidative to reducing leads to almost negligible change of ${ }^{5} D_{0} \rightarrow{ }^{7} F_{1}$ spectral line intensity. So, according to these results, the content of oxygen vacancies in ceria nanocrystals treated in oxidative and reducing atmospheres should be almost the same. This conclusion is, however, in some contradiction with the strong difference between the spectra of $\mathrm{Eu}^{3+}$-doped ceria nanocrystals treated in oxidative and reducing atmospheres, as formation of detectable $\mathrm{Ce}^{3+}$ luminescence band in the spectra of ceria treated in reducing atmosphere requires relatively high 

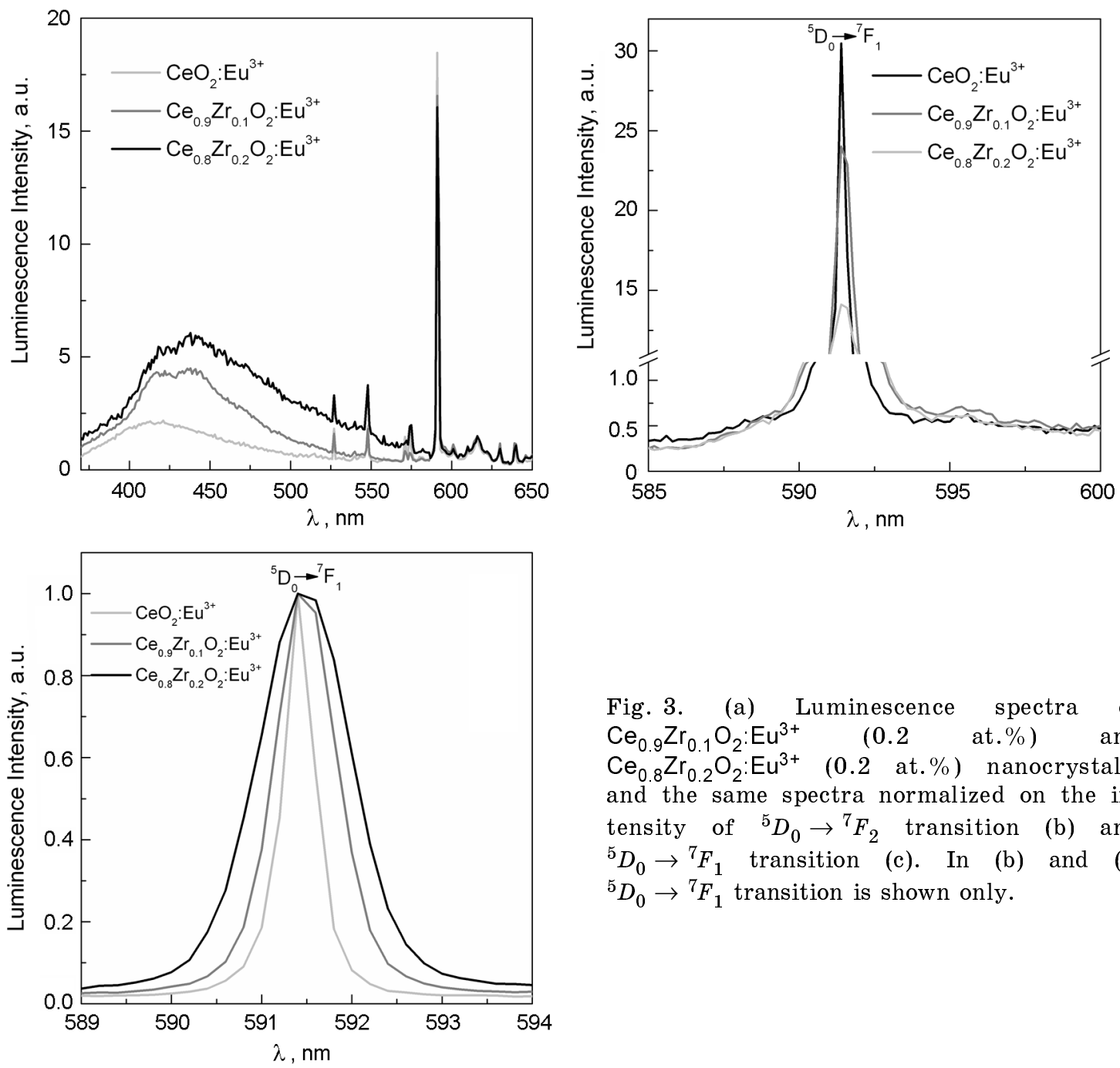

concentrations of oxygen vacancies. However, it should be noted that the concentration of oxygen vacancies determined by relative intensity of ${ }^{5} D_{0} \rightarrow{ }^{7} F_{1}$ luminescence can be underestimated as oxygen vacancies during heat treatment in reducing atmosphere should form preferably near the surface of nanoparticle, so the change of the symmetry induced by formation of these vacancies can only partially be felt by $\mathrm{Eu}^{3+}$ ions, so real concentration of oxygen vacancies in ceria nanocrystals treated in reducing atmosphere can be few times more.

Incorporation of $\mathrm{Zr}^{4+}$ ions instead of $\mathrm{Ce}^{4+}$ ones should lead to increase of the number of oxygen vacancies. According to [12], for an intermediate composition such as $\mathrm{Ce}_{0.5} \mathrm{Zr}_{0.5} \mathrm{O}_{2}$, a significant distortion of oxygen sublattice around zirconium ions leads to increase of $\mathrm{Zr}-\mathrm{O}$ distances for two of eight oxygen ions surrounding $\mathrm{Zr}^{4+}$ ion $(0.26 \mathrm{~nm}$ as compared to $0.2312 \mathrm{~nm}$ for $\mathrm{Ce}-\mathrm{O}$ bond in pure $\mathrm{CeO}_{2}$ ). The longer $\mathrm{Zr}-\mathrm{O}$ dis-

tances for some oxygen ions and the consequent weakness of the bond decreases the energy of oxygen vacancies formation. This fact is confirmed by easier oxygen diffusion in these materials, and, so by improved catalytic properties $[15,16]$. The process of formation of oxygen vacancies in mixed ceriazirconia nanocrystals can be studied using ${ }^{5} D_{0} \rightarrow{ }^{7} F_{1} /{ }^{5} D_{0} \rightarrow{ }^{7} F_{2}$ ratio of $\mathrm{Eu}^{3+}$ ions as well. In the Fig. $3 a$ the luminescence spectra of $\mathrm{Eu}^{3+}$-doped ceria-zirconia nanocrystals with different zirconium content after treatment in reducing atmosphere are shown. As one can see, all the spectra consist of the wide $5 d \rightarrow 4 f \mathrm{Ce}^{3+}$ luminescence band which maximum is red-shifted at increase of zirconium content (from $415 \mathrm{~nm}$ for pure ceria nanocrystals to $440 \mathrm{~nm}$ for $\mathrm{Ce}_{0.8} \mathrm{Zr}_{0.2} \mathrm{O}_{2}$ ), and narrow $\mathrm{Eu}^{3+}$ transitions. Increase of zirconium content from $\mathbf{0}$ to $20 \%$ leads to 3 -fold increase of intensity of $\mathrm{Ce}^{3+}$ luminescence band and twofold decrease of relative intensity of ${ }^{5} D_{0} \rightarrow{ }^{7} F_{1}$ 
transition of $\mathrm{Eu}^{3+}$ ions (see Fig. 3b). Also the width of ${ }^{5} D_{0} \rightarrow{ }^{7} F_{1}$ spectral line increases in three times as compared to the with of this line for pure ceria nanocrystals.

All these effects can be undoubtedly ascribed to increase of the content of oxygen vacancies in the ceria structure. As was mentioned before, formation of two $\mathrm{Ce}^{3+}$ ions due to $\mathrm{Ce}^{4+} \rightarrow \mathrm{Ce}^{3+}$ transition in $\mathrm{CeO}_{2}$ structure require one oxygen vacancy for charge compensation, so increase of $\mathrm{Ce}^{3+}$ luminescence band intensity is a reliable sign of increase of the content of oxygen vacancies during zirconium incorporation to ceria structure. The change of the content of oxygen vacancies can be estimated from the change of relative ${ }^{5} D_{0} \rightarrow{ }^{7} F_{1}$ luminescence intensity (Fig. 3b). According to Fig. 2a twofold decrease of ${ }^{5} D_{0} \rightarrow{ }^{7} F_{1}$ luminescence intensity corresponds to increase of $\mathrm{Eu}^{3+}$ concentration from 0.2 at. $\%$ to 2 at. $\%$ (corresponding to increase of the content of oxygen vacancies from $0.05 \%$ to $0.5 \%$ ). So, the same tenfold increase of the content of oxygen vacancies should observed at incorporation of $20 \%$ of zirconium ions. Even taking into account the fact that this method underestimates the content of oxygen vacancies formed during treatment in reducing atmosphere, the effect of doping by zirconium ions on the concentration of oxygen vacancies in ceria is evident. The strong difference between negligible change of ${ }^{5} D_{0} \rightarrow{ }^{7} F_{1}$ luminescence intensity at treatment atmosphere variation (Fig. 2b) and sufficient decrease of ${ }^{5} D_{0} \rightarrow{ }^{7} F_{1}$ luminescence intensity at zirconium incorporation confirms the suggestion that in ceriazirconia in contrast to pure ceria nanoparticles, oxygen vacancies are formed not only near nanocrystal surface, but within whole nanoparticle enabling deep-seated $\mathrm{Eu}^{3+}$ ions to feel the change in their concentration.

\section{Conclusions}

The processes of formation of oxygen vacancies in mixed ceria-zirconia nanocrystals were studied using the intensity of ${ }^{5} D_{0} \rightarrow{ }^{7} F_{1}$ transition of doped $\mathrm{Eu}^{3+}$ ions. In contrast to ceria nanocrystals treated in reducing atmosphere, for which oxygen vacancies are formed preferably near nanocrystal surface, and almost do not lead to the change of symmetry of surrounding of $\mathrm{Eu}^{3+}$ doped ions, formation of oxygen vacancies within whole nanoparticle was shown for mixed ceria-zirconia nanocrystals, so the influence of these vacancies on the ${ }^{5} D_{0} \rightarrow{ }^{7} F_{1} /{ }^{5} D_{0} \rightarrow{ }^{7} F_{2}$ ratio of doped $\mathrm{Eu}^{3+}$ ions is sufficient. Overall, change of $20 \%$ of $\mathrm{Ce}^{4+}$ cations to $\mathrm{Zr}^{4+}$ ones leads to two-fold decrease of ${ }^{5} D_{0} \rightarrow{ }^{7} F_{1}$ intensity corresponding to tenfold increase of the content of oxygen vacancies that should lead to higher oxygen mobility in mixed ceria-zirconia nanocrystals.

The publication contains the results of studies conducted by President's of Ukraine grant for competitive projects $\Phi 75 / 29864$ "Development of redox-active materials based on oxide nanocrystals with cations with variable valence for control of the level of reactive oxygen species in he living cell" of the State Fund for Fundamental Research.

\section{References}

1. A.Trovarelli, P.Fornasiero, Catalysis by Ceria and Related Materials, Imperial College Press, London (2013).

2. M.G.Bellino, D.G.Lamas, N.E.Walsoe de Reca, Adv. Funct. Mater., 16, 107 (2006).

3. D.A.Andersson, S.I.Simak, N.V.Skorodumova et al., Proc. Nat.Acad.Sci., 103, 3518 (2006).

4. Y.Malyukin, P.Maksimchuk, V.Seminko et al., J. Phys. Chem. C, 122, 16406 (2018).

5. M.Nakayama, M.Martin, Phys.Chem.Chem. Phys., 11, 3241 (2009).

6. A.Masalov, O.Viagin, P.Maksimchuk et al., $J$. Lumince., 145, 61 (2014).

7. V.Seminko, P.Maksimchuk, I.Bespalova et al., Phys. Status Solidi B, 254, DOI: 10.1002/pssb.201600488 (2017).

8. E.Okrushko, V.Seminko, P.Maksimchuk et al., Low Temp. Phys., 43, 636 (2017).

9. B.Tiseanu, V.Parvulescu, M.Sanchez-Dominguez, M.Boutonnet, Appl.Phys. Rev., 112, 013521 (2012).

10. D.Avram, C.Gheorghe, C.Rotaru et al., J.Alloys Compd., 616, 535 (2014).

11. P.Maksimchuk, V.Seminko, I.Bespalova, A.Masalov, Functional Materials, 21, 254 (2014).

12. T.Montini, M.Melchionna, M.Monai, P.Fornasiero, Chem. Rev., 116, 5987 (2016).

13. T.Masui, T.Ozaki, K.I.Machida, G.Y.Adachi, J.Alloys Compd., 303, 49 (2000).

14. E.Mamontov, T.Egami, R.Brezny et al., $J$. Phys.Chem. B, 104, 11110 (2000).

15. C.Diagne, Hicham Idriss, A.Kiennemann, Catal.Commun., 3, 565 (2002).

16. G.Balducci, J.Kaspar, P.Fornasiero et al., $J$. Phys.Chem. B, 102, 557 (1998). 